\title{
Hepatitis delta virus in homosexual men in Sydney
}

\author{
N J BODSWORTH, * B DONOVAN, * J GOLD, $\dagger$ Y E COSSART $\ddagger$ \\ From the Departments of *Public Health and $\ddagger$ Infectious Diseases, University of Sydney, and the $\dagger$ Albion Street \\ (AIDS) Centre, Sydney Hospital, Sydney, Australia
}

SUMMARY In countries not generally endemic for hepatitis B, homosexual men who are carriers of hepatitis B surface antigen (HBsAg) have to date largely been spared additional delta virus infection. A focus of homosexually acquired delta has, however, recently been identified in Calfornia. To assess the prevalence and risk factors for delta virus infection in homosexual men in Sydney, we tested the sera of 204 homosexual men with acute or chronic hepatitis B infection for total antibody to delta and delta antigen. Total antibody to delta was detected in eight men and delta antigen in one other (4.4\% of the total). All men with antibody or antigen had intravenous drug use as a risk factor. Overall nine of $22(40.9 \%)$ male homosexual intravenous drug users had serological evidence of delta infection. Delta positive patients tended to be younger, to have engaged in prostitution, to have more severe chronic liver disease, to be more likely to have a symptomatic acute illness, and to be less likely to express hepatitis $\mathrm{Be}$ antigen $(\mathrm{HBeAg})$ in their sera.

Though the homosexual transmission of delta infection cannot be concluded from this study, the detection of delta markers in nine homosexual men (including four prostitutes) suggests considerable potential for dissemination of this virus homosexually.

The hepatitis delta virus (HDV) is a defective, small $(36 \mathrm{~nm})$, single stranded, circular RNA virus that depends on the hepatitis B virus (HBV) for certain helper functions, most notably the provision of surface antigen (HBsAg) in which it too is encapsulated. In this respect it appears to be unique among animal viruses and most closely resembles the satellite RNAs of certain plant viruses. ${ }^{1}$ Clinically, delta infection is manifested either as coinfection with acute hepatitis B or as superinfection in chronic $\mathrm{HBsAg}$ carriers. Superinfection is invariably accompanied by liver damage, and most patients develop cirrhosis within five years. ${ }^{2}$

Since its discovery in southern Italy in $1977,{ }^{3}$ the epidemiology of HDV infection has been studied extensively, and the global distribution has largely been defined. ${ }^{4}$ In countries endemic for HBV, HDV has a widespread if irregular distribution. In contrast to the perinatal transmission of $\mathrm{HBV}$ in these lands, HDV seems to be mostly spread by close family contact, usually in the first 15 years of life. ${ }^{4}$ Circumstantial evidence, such as finding higher rates in postwar than prewar Italian immigrants to Australia, ${ }^{5}$ suggests that HDV dissemination to many areas

Address for reprints: Dr N J Bodsworth, Department of Public Health, University of Sydney, NSW 2006, Australia

Accepted for publication 1 February 1989 endemic for HBV may have occurred relatively recently. Once the delta agent is introduced into a susceptible population, its dissemination can be rapid. This is illustrated by the periodical epidemics of delta hepatitis in South America Indian tribes ${ }^{6}$ and by longitudinal studies of European intravenous drug users. ${ }^{78}$ No HDV was detected before 1973 in Swedish intravenous drug users with $\mathrm{HBsAg}$, but its prevalence had climbed to over $70 \%$ by $1981 .^{7}$ In countries where HBV is not endemic in the general population, HDV has a varied distribution in groups at risk for HBV. In studies from northern Europe and the United States of America over $70 \%$ of intravenous drug users with HBsAg had markers of HDV infection, ${ }^{6-8}$ and about half the haemophiliacs with HBsAg also had concomitant HDV infection. ${ }^{69}$

In contrast, homosexual men with $\mathrm{HBsAg}$ have largely been spared, and most prevalence studies of European, North American, and Australian homosexuals have yielded rates similar to those in the general population. ${ }^{4610} \mathrm{~A}$ focus of homosexually acquired HDV appeared in California in about 1982, however," and by 1985 about $13 \%$ of 170 homosexual men with HBsAg had HDV antibody, of whom only $46 \%$ were intravenous drug users. ${ }^{12}$ To assess the prevalence of the hepatitis delta virus in homosexual men in Sydney we sought markers of HDV infection in 204 homosexual men with acute or chronic hepatitis B. 


\section{Patients and methods}

Approval for this study was obtained from the Ethics Committee of the Faculty of Medicine, University of Sydney.

\section{STUDY POPULATION}

All 216 homosexual or bisexual men with evidence of current or recent HBV infection who attended one of three inner metropolitan health clinics in Sydney between 1984 and 1987 were eligible for the study. Stored serum samples from 204 (94.4\%) were available. HBV infection was defined by detecting $\mathrm{HBsAg}$ on at least one occasion or by documented seroconversion, as shown by the appearance of antibody to hepatitis B core antigen ( $\mathrm{HBcAg})$, during the study period. The three clinics were the Albion Street (AIDS) Centre $(n=103)$, the Gay Men's Health Study at the Sydney Sexually Transmissible Disease (STD) centre $(n=18)$, both units of Sydney Hospital, and the Taylor Square Private (STD) clinic $(n=82)$. Demographic and clinical data were obtained by a confidential review of each patient's medical records.

Each patient was classified as having chronic or acute HBV infection, which was asymptomatic or symptomatic and acute or not, depending on the following criteria.

\section{Chronic HBV carrier}

Asymptomatic carrier. Men whose test results for HBsAg were positive on two occasions more than six months apart and for whom no illness suggestive of hepatitis had been recorded in the 12 months preceding the first of these tests $(n=82)$.

Symptomatic carrier. Men who had had two positive test results for HBsAg more than six months apart after an illness suggestive of acute hepatitis $(n=50)$. Four had firm evidence of acute infection, such as $\mathrm{HBcAg}$ IgM or a recent (within 12 months) negative result for $\mathrm{HBsAg}$, and were described as being "chronic with recent acute illness". The remaining 46 were described as being "chronic with possible recent acute illness". This distinction was made in an attempt to assess the occurrence of superinfection rather than coinfection with HDV.

Probable carrier. Men with incidental findings of a single (or two within six months) positive test result for HBsAg with no recent (within 12 months) illness suggestive of acute viral hepatitis $(n=31)$.

\section{Acute $\mathrm{HBV}$}

Definite acute. Men with acute hepatitic illness and a positive HBsAg test result who had had a negative result for $\mathrm{HBsAg}$ within the preceding 24 months $(n=17)$.
Probable acute. Men with acute hepatitic illness and a positive HBsAg test result who had not been tested for HBsAg in the previous 24 months $(n=15)$.

Asymptomatic acute. Men with asymptomatic seroconversion from no markers for $\mathrm{HBV}$ to a positive test result for $\mathrm{HBcAg}$ with no intervening hepatitic illness and no positive $\mathrm{HBsAg}$ result on screening $(n=12)$.

\section{LABORATORY METHODS}

We analysed the most recently collected of stored serum samples. For patients who had started taking zidovudine, we examined the sample taken most recently before starting treatment. We assayed samples for $\mathrm{HBsAg}, \mathrm{HBcAg}$, hepatitis $\mathrm{Be}$ antigen ( $\mathrm{HBeAg}$ ), and total antibody to HDV by enzyme immunoassay using commercial kits (Abbott EIA; Abbott Laboratories, North Chicago, USA) and for delta antigen by Deltassay Ag (Noctech, Dublin). Limited kit numbers precluded testing men without antibody to human immunodeficiency virus (HIV) who were probable carriers of delta antigen if they gave negative results for antibody to HDV.

\section{STATISTICAL ANALYSIS}

Statistical analysis was performed using the SAS statistical package. Continuous variables such as age were analysed by Student's $t$ test. Ages approximated log normal distribution. Serum alanine transferase (ALT) activities did not, and were therefore dichotomised at $250 \%$ of the upper normal limit $(100 \mathrm{IU} / \mathrm{l})$. Dichotomous variables were analysed by the $\chi^{2}$ method using continuity adjustment or Fisher's exact method. Multivariate logistical regression analysis was performed to assess which factors were independently associated with HDV infection. All p values were two tailed.

\section{Results}

Serum samples were available for analysis from 204 $(94.4 \%)$ of the 216 patients identified. Their mean age was 33 (range 17-55) years. Overall, $23(11.3 \%)$ were first or second generation immigrants from the Mediterranean basin, Asia, or Latin America. Twenty two $(10.8 \%)$ gave a history of intravenous drug use, and $15(7.4 \%)$ had a history of working as men prostitutes. The HIV antibody status of $186(91.2 \%)$ was known, 101 (54.3\%) of whom had positive results. We knew the HBeAg status of 159 out of 160 chronic HBsAg carriers, of whom 97 (61\%) had positive results.

Total antibody to HDV was detected in the serum of eight men: seven with chronic and one with acute HBV infection. Delta antigen without antibody was detected in the serum of one intravenous drug user with antibody to HIV during the first phase of an acute 
biphasic hepatitic illness. Unfortunately, follow-up serum samples were not available to show whether an antibody response to HDV appeared later. Thus, nine (4.4\%) of 204 men had serological evidence of HDV infection (table 1).

Men with HDV infection were on average younger than the rest of the study population (table 2), but this was not an independent predictor when intravenous drug use was controlled for (table 3 ). All nine men with HDV infection gave a history of intravenous drug use. Four (44.4\%) of nine men with HDV infection had been prostitutes compared with 11 of $195(5.6 \%)$ in whom no HDV was detected (table 2). Multivariate linear regression analysis, however, suggested that a history of prostitution was not in itself an independent predictor for a positive result for HDV: nine $(60 \%)$ of the 15 prostitutes were also intravenous drug users. Overall, nine $(\mathbf{4 0 . 9 \% )}$ ) 22 homosexual intravenous drug users had evidence of HDV infection (table 4).

$\mathrm{HBeAg}$ was expressed much less often in chronic HBV carriers who had positive results for HDV $(p=0.009)$ (table 4). There was also a trend towards greater serum ALT activities in HDV positive men, which became significant if analysis was restricted to

Table 1 Serum antibody to hepatitis delta and delta antigen in 204 homosexual men by clinical criteria

\begin{tabular}{lrl}
\hline & No & $\begin{array}{l}\text { No (\%) with } \\
\text { antibody to } \\
\text { hepatitis delta }\end{array}$ \\
\hline Chronic hepatitis & 79 & $1(1 \cdot 3)$ \\
Asymptomatic carrier & 4 & 0 \\
Symptomatic carrier & 46 & $4(8 \cdot 7)$ \\
$\quad$ Definite acute & 31 & $2(6 \cdot 5)$ \\
$\quad$ Possible acute & 160 & $7(4 \cdot 4)$ \\
Probable carrier & 17 & 0 \\
Acute hepatitis & 15 & $2 *(13 \cdot 3)$ \\
Definite acute & 12 & 0 \\
Probable acute & 44 & $2(4 \cdot 6)$ \\
Asymptomatic acute & 204 & $9(4 \cdot 4)$ \\
Total acute & & \\
Total & &
\end{tabular}

*One of these gave positive result for delta antigen only.

Table 2 Selected demographic characteristics of 204 homosexual men with or without delta markers, Sydney 1984-7

\begin{tabular}{llll}
\hline & $\begin{array}{l}\text { Delta } \\
\text { positive } \\
(n=9)\end{array}$ & $\begin{array}{l}\text { Delta } \\
\text { negative } \\
(n=195)\end{array}$ & $p$ \\
\hline $\begin{array}{l}\text { Mean (range) age (years) } \\
\text { No (\%) intravenous drug }\end{array}$ & $96.4(22-32)$ & $33 \cdot 1(17-55)$ & 0.024 \\
$\begin{array}{l}\text { users } \\
\text { No (\%) prostitutes }\end{array}$ & $4(44.4)$ & $11(6.7)$ & $<0.0001$ \\
$\begin{array}{l}\text { No (\%) immigrants from } \\
\text { countries where HDV } \\
\text { is endemic }\end{array}$ & $1(11 \cdot 1)$ & $21(10.7)$ & NS \\
\hline
\end{tabular}

Table 3 Correlates of hepatitis delta virus (HDV) positivity in 22 male homosexual intravenous drug users

\begin{tabular}{|c|c|c|c|}
\hline & $\begin{array}{l}\text { Delta } \\
\text { positive }\end{array}$ & $\begin{array}{l}\text { Delta } \\
\text { negative }\end{array}$ & $p$ \\
\hline \multirow{4}{*}{$\begin{array}{l}\text { Mean (range) age (years) } \\
\text { No (\%) prostitutes } \\
\text { No (\%) immigrants from } \\
\text { countries where HDV } \\
\text { is endemic } \\
\text { No }(\%) \text { with antibody to } \\
\text { HIV } \\
\text { No (\%) with HBeAg } \\
\text { No (\%) w with ALT } \\
\text { activity > } 100 \mathrm{IU} / 1\end{array}$} & $\begin{array}{l}26 \cdot 4(22-32) \\
4 / 9(44 \cdot 4)\end{array}$ & $\begin{array}{l}26 \cdot 2(17-35) \\
5 / 13(38 \cdot 5)\end{array}$ & $\begin{array}{l}\text { NS } \\
\text { NS }\end{array}$ \\
\hline & $1 / 9(11 \cdot 1)$ & $0 / 13$ & NS \\
\hline & $\begin{array}{l}4 / 9(44 \cdot 4) \\
1 / 7(14 \cdot 3)\end{array}$ & $\begin{array}{l}9 / 13(69 \cdot 2) \\
8 / 10(80 \cdot 0)\end{array}$ & $\begin{array}{l}\text { NS } \\
0.015\end{array}$ \\
\hline & $3 / 5(60.0)$ & $4 / 10(40 \cdot 0)$ & NS \\
\hline
\end{tabular}

*When known.

†Percentage of chronic HBV carriers, when known.

HIV = Human immunodeficiency virus.

$\mathrm{HBeAg}=$ Hepatitis B e antigen.

ALT $=$ Alanine transferase.

Table 4 Laboratory variables in homosexual men with markers of hepatitis delta virus (HDV) infection

\begin{tabular}{|c|c|c|c|}
\hline & $\begin{array}{l}\text { Delta } \\
\text { positive }\end{array}$ & $\begin{array}{l}\text { Delta } \\
\text { negative }\end{array}$ & $p$ \\
\hline \multirow{3}{*}{$\begin{array}{l}\text { No (\%) with antibody to } \\
\text { HIV } \\
\text { No }(\%)+\text { with } \mathrm{HBeAg} \\
\text { No }(\%) \dagger \text { with ALT } \\
\text { activity > } 100 \mathrm{IU} / 1 \\
\text { No }(\%) \dagger \text { with } \mathrm{ALT} \\
\text { activity }>100 \mathrm{IU} / 1 \\
\text { without } \mathrm{HBeAg}\end{array}$} & $\begin{array}{l}4 / 9(44 \cdot 4) \\
1 / 7(14 \cdot 3)\end{array}$ & $\begin{array}{l}97 / 177(54 \cdot 8) \\
101 / 152(66 \cdot 5)\end{array}$ & $\begin{array}{l}\text { NS } \\
0.009\end{array}$ \\
\hline & $3 / 5(60 \cdot 0)$ & $33 / 132(25 \cdot 0)$ & $0 \cdot 113$ \\
\hline & $3 / 4(75 \cdot 0)$ & $3 / 42(7 \cdot 1)$ & 0.005 \\
\hline
\end{tabular}

-When known.

tPercentage of chronic HBV carriers, when known.

HIV = Human immunodeficiency virus.

$\mathrm{HBeAg}=$ Hepatitis B e antigen.

ALT $=$ Alanine transferase.

patients without $\mathrm{HBeAg}(\mathrm{p}=0.005)($ table 3). HDV infection was not associated with HIV infection (table 3 ). The incidence of none of the above variables varied significantly between the three clinics.

\section{Discussion}

Kreek et al associated concurrent HIV infection with chronic delta antigenaemia without antibody to HDV (Third international conference on AIDS, Washington DC, 1987). This can occur either by a failure to mount an antibody response to acute HDV infection, ${ }^{15}$ or by loss of antibody and subsequent reappearance of antigen in established HDV infection. ${ }^{16}$ None of our HIV antibody positive chronic HBV carriers, however, had detectable antigen in their serum and no follow-up serum samples were available from our single antigenaemic patient. Perhaps because the spread of delta infection was limited in our study population, we were unable to confirm the findings of Kreek et al.

Nine $(40.9 \%)$ of 22 intravenous drug users in this 
study had positive results for some marker of HDV infection. The only previous report of $\mathrm{HDV}$ in intravenous drug users (not homosexual) in Sydney, in 1982 , found delta antibody in $3 / 8(37.5 \%)$ of $\mathrm{HBV}$ carriers tested. ${ }^{17}$ As most of those patients were from a specialist gastroenterology unit and were presumably more ill, our finding of a $40.9 \%$ incidence in ambulatory generally well men suggests continued dissemination of delta infection in this group.

As all the men with delta infection had intravenous drug use as a risk factor, homosexual transmission cannot be concluded from this study. This is consistent with findings from Melbourne, where delta antibody had not been detected in $300 \mathrm{HBsAg}$ positive serum samples from homosexual men to $1987 .^{10}$ This contrasts with the findings of Solomon et al that $54 \%$ of 22 American homosexual men with delta markers had no history of intravenous drug use and that infection was independently associated with rectal trauma and the number of sexual partners in the previous two years. ${ }^{12}$

The explanations for the absence of HDV infection in homosexual men in our study who were not intravenous drug users could be biological, epidemiological, or both. Parenteral inoculation may be the much preferred means of transmission for this virus. This is somewhat challenged by the findings of Solomon $e a_{l^{12}}$ and the knowledge that close, familial, horizontal, non-sexual contact is the chief means of dissemination of HDV in countries where it is endemic. ${ }^{4}$ Further, the well-documented inverse association between delta infection and expression of $\mathrm{HBeAg}$ may provide some protection for homosexual men. ${ }^{18}$ Studies of homosexual men with $\mathrm{HBsAg}$ have shown that about $65 \%$ express $\mathrm{HBeAg}$ in their serum compared with only about $10 \%$ of blood donors with HBsAg. ${ }^{192}$ In our study, $66.5 \%$ of homosexual men with chronic HBV without delta antibody expressed $\mathrm{HBeAg}$ in serum, as opposed to only $14.3 \%(1 / 7)$ with delta antibody $(\mathrm{p}<0.01)$.

The widespread adoption of "safer" sexual practices by homosexual men in the light of the AIDS epidemic $^{21}$ may have occurred in time to hinder dissemination of the delta agent by sexual means. It may not be possible to generalise about the study population. Four delta positive men had worked as prostitutes. Their clients tended to be married bisexual men from outer suburban areas, ${ }^{22}$ and may have been less likely to attend the inner city clinics from which the study population was drawn. Thus transmission to them of HDV may have been missed. Future surveys would need to exclude this possibility.

This study was supported by a grant from the NHMRC Commonwealth AIDS Research Grants Committee. We also wish to thank Dr Carmella Law and Mr G Holt at the Sydney STD Centre for help in data collection, Miss Megan Nelson of Taylor Square Private Clinic for her laboratory assistance, Abbott Diagnostics for donating antibody test kits, and Carter-Wallace (Australia) as agents for Noctech for providing antigen test kits at cost. This study is based on a research treatise by Dr Bodsworth as part of the requirements for the degree of Master of Medicine in Venereology at the University of Sydney.

\section{References}

1 Rizzetto M. The delta agent. Hepatology 1983;3:729-37.

2 Fattovich G, Boscaro S, Noventa F, et al. Influence of hepatitis delta virus infection on progression to cirrhosis in chronic hepatitis type B. J Infect Dis 1987;155:931-5.

3 Rizzetto M, Canese MG, Arico S, et al. Immunofluorescence detection of a new antigen-antibody system (delta/anti-delta) associated with hepatitis B virus in liver and serum of $\mathbf{H B s A g}$ carriers. Gut 1977;18:997-1003.

4 Ponzetto A, Forzani B, Parravicini PP, Hele C, Zanetti A, Rizzetto M. Epidemiology of hepatitis delta (HDV) infection. Eur $J$ Epidemiol 1985;1:257-3.

5 Cossart YE. Big fleas have little fleas. Med J Aust 1986;145:122-3.

6 Maynard JE, Hadler SC, Fields HA. Delta hepatitis in the Americas: an overview. Prog Clin Biol Res 1987;234:493-6.

7 Hansson BG, Moestrup T, Widell A, Nordenfelt A. Infection with delta agent in Sweden: introduction of a new hepatitis agent. $J$ Infect Dis 1982;146:472-8.

8 Ramalho F, Cavalho G, Bonino F, Baptista A, de Moura MC. Clinical and epidemiological significance of hepatitis delta (HDV) infection in chronic HBV carriers in Portugal. Prog Clin Biol Res 1987;234:409-17.

9 Rizzetto M, Purcell RH, Gerin JL. Epidemiology of HBVassociated delta agent: geographical distribution of anti-delta and prevalence in polytransfused $\mathrm{HBsAg}$ carriers. Lancet 1980;ii:1215-9.

10 Dimitrakis M, Gust I. Prevalence of delta infection in Australia and the Western Pacific region. In: Zuckerman AJ, ed. Viral hepatitis and liver disease. New York: Alan Liss, 1988:433-5.

11 De Cock KM, Govindarajan S, Redeker AG. Nonpercutaneous spread of delta infection. $J$ Infect Dis 1985;152:845.

12 Solomon RE, Kaslow RA, Phair JP, et al. Human immuriodeficiency virus and hepatitis delta virus in homosexual men. Ann Intern Med 1988;108:51-4.

13 Caredda F, Antinori S, Re T, Pastecchia C, Moro M. Course and prognosis of acute HDV hepatitis. Prog Clin Biol Res 1987;234:267-76.

14 Shattock AG, Irwin FM, Morgan BM, et al. Increased severity and morbidity of acute hepatitis in drug abusers in simultaneously acquired hepatitis $B$ and hepatitis $D$ virus infections. Br Med J 1985;290:1377-80.

15 Grippon P, Ribiere O, Cadranel JF, et al. Long-term delta antigenaemia without appearance of delta antibody in two immunodeficient patients. Lancet 1987; 1031.

16 Shattock AG, Finlay H, Hillary IB. Possible reactivation of hepatitis D with chronic $\delta$ antigenaemia by human immunodeficiency virus. $\mathrm{Br}$ Med J 1987;294:1656-7.

17 Williams GV, Cossart YE. Delta associated hepatitis in Australia. Aust NZ J Med 1983;13:231-5.

18 Rizzetto M, Verme G, Recchia S, et al. Chronic hepatitis in carriers of hepatitis B surface antigen, with intrahepatic expression of the delta antigen. An active and progressive disease unresponsive to immunosuppressive treatment. Ann Intern Med 1983;98:437-41.

19 Szmuness W, Neurath AR, Stevens CE, Strick N, Harley EJ. Prevalence of hepatitis B " $e$ " antigen and its antibody in various HBsAg carrier populations. Am J Epidemiol 1981;113:113-21.

20 Simmons PD. E antigen among male homosexual patients. Br Med $J$ 1977;ii: 1458.

21 Donovan B. Social and behavioural aspects of AIDS: measures of behaviour change. Proceedings of the Third National Conference on AIDS. Canberra: Australian Government Publishing Service, 1988;167-71.

22 Griggs E. A mobile outreach programme directed towards male prostitutes, transsexual prostitutes and intravenous drug users in Sydney. Proceedings of the Third National Conference on AIDS. Canberra: Australian Government Publishing Service, 1988:384-7. 